\title{
1A1-H-73 空気式パラレルマニピュレータを用いた仮想拘束面の導入による操作支援マスタ装置の
} 開発

○高岩 昌弘 (岡山大), 則次 俊郎 (岡山大), 白川 悟 (岡山大)

Development of operational supporting master device using pneumatic parallel manipulator introducing virtual restriction wall

OTakaiwa.M (Okayama univ.), Noritsugu.T (Okayama univ.), Shirakawa.S (Okayama univ)

原子炉施設なぜ人が容易に立ち入れない環境では人が操縦するロボットに作業を代行させるマスタ・スレーブンステムが有効と なる、本研究では従来より提案されているバイラテラル機能に加えて作業環境に応じてマス夕操作者を支援する手法を提案する。 従来より作業に適した工具の動特性を実現する手法が提案されているが本研究では工具の動特性そのものを実現するのではなく， OpenGL を用いて仮想的な拘束面を構築し，拘束面からの接触反力を操作支援に利用することを考える。例えば作業空間内に拉 いてスレーブの手先を直線状に移動させたい場合, マスタ側の作業空間内に定規のような機械要素が存在すれば都合がよい，本手 法ではこの場合の定規に相当する機能を実現する，提案する手法の有用性を実駼により検証する。

1A1-H-74＼cjkstart頭部の形状と運動を考慮した音響テレイグジスタンスロボット：テレヘッド

○戸嶋 䉷樹 (NTT), 青木 茂明 (NTT), 平原 達也 (NTT)

Auditory tele-presece robot, " TeleHead" , with a steerable life-mask dummy head

OToshima.I (NTT CS Lab.), Aoki.S (NTT CS Lab.), Hirahara.T (NTT CS Lab.)

遠隔の音環境をロボットによって伝達する場合, 受け手のヒトの身体性を考虑することが重要である. 音環境を理解する際の基 本的機能の一つである音像定位においては, 自己の頭部形状に由来する頭部の音響的性質, 頭部伝達関数 (HRTF) が重要な手が かりとなる、一方, 音環境の理解への手がかりは受動的な情報だけではない、積極的に頭部を動か寸ことも音像定位を行う上での 重要な手がかりとなることが知られている。 そこで, 我々は使用者の頭部形状と頭部運動を遠隔に再現することで, 遠隔の音環境 をリアルタイムに再現するロボットのコンセプトを提案し，音響テレイグジスタンスロボット，テレヘッド 1 号機，を製作した． そして，その改良版であるテレヘッド 2 号機を製作した。本稿では湆響テレイグジスタンスロボットにとって重要な性能である， 駆動時の騒音特性, 頭部連動への追従性能, ダミーヘッドの形状再現精度について評価した。また, 使用者に遠方の音環境を正確 に伝達できているか評価するために音像定位実験を行った。テレヘッド 1 号機の追従時の遅延は $200 \mathrm{~ms}$ であったが, テレへッド

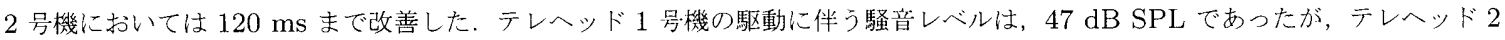

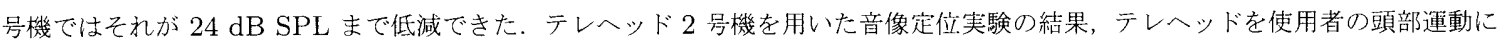
追従動作させることにより，ダミーヘッドのモデルとなった被験者だけでなく，全く異なる頭部形状を持つ被験者であっても，水 平面定位精度が向上することが分かった．また，正中面の定位精度は異なる頭部形状を持つ被験者では向上しなかった。これらの 実験結果は，音響テレイグジスタンスロボットが使用者に似た形状の頭部を持つこと及び，使用者の頭部運動に追従動作すること の有效性を示すものである.

\section{A1-H-75 Proactive Desk を用いたカ覚付き情報キオスクの提案}

○吉田 俊介 $(\mathrm{ATR})$, 柿田 充弘 $(\mathrm{ATR})$, 野間 春生 $(\mathrm{ATR})$, 鉄谷 信二 $(\mathrm{ATR})$

A proposal of information kiosks with a force feedback using the Proactive Desk

OYoshida.S (ATR), Kakita.M (ATR), Noma.H (ATR), Tetsutani.N (ATR)

筆者らは情報機器との入出カインタフェースとして, 視覚や聴覚情報以外に触覚情報をも利用可能なデスクトップ操作環境 「ProactiveDesk」を提案している。これはリニア誘導モー夕の原理を応用することにより机上物体の位置制御ができるものであ り, 結果的に二次元方向の力覚を利用者に提示することが可能である. 本論文では, とりわけ不特定の背景を持つ利用者が多数想 定される公共的な端末，博物館や美術館に置かれるような情報キオスクを想定し，本装䈯を用い物理的な情報を付加することによ り，どのようなサービスの提供が可能であるかを検討し，実装例をもとに力覚付き情報キオスクの提案を行う．

\section{A1-H-76 プロアクティブヒューマンインターフェースの研究}

一第 1 報人間型アクティブインターフェースの開発一

○倉爪 亮 (九州大), 内田 誠一 (九州大), 谷口 倫一郎 (九州大), 長谷川 魅 (九州大)

Study on Proactive Human Interface

- Development of Humanoid-type Active Interface -

OKurazume.R (Kyushu University), Uchida.S (Kyushu University), Taniguchi.R (Kyushu University), Hasegawa.T (Kyushu University)

我々は「ブロアクティブヒューマンインターフェース」の研究を行っている。この研究の目的は, "人間からの詳細なデマンド に寄らない新たな駆動原理（プロアクティブ技術）にに基づき，従来の仮想メディアだけではなく”実体としてのロボット技術”の 活用することで，人とコンピュータシステムに存在する坦根を低減化し，様々な人にとって自然で使いやすいヒューマンインタ フェースの枠組みを提供しようというものである. 本報告では提案する「プロアクティブヒューマンインターフェース」の概念と 試作した人間型アクティブインターフェースおよび実体を用いた遠隔コミュニケーションのための予備実験の様子を紹介する。ま た人間の行動意図の推定手法として，連繶 DP マッチングを用いたジェスチャのスポッティング認識手法を提案する。

\section{•マイクロ・ナノ作業 1}

1A1-H-25 1-kHz 高速可変焦点レンズによる動的な顕微鏡下対象への高速焦点面トラッキング 